\title{
Perbandingan Profil Lipid dan Penentuan Indeks Aterogenik pada Tikus Putih Jantan yang Diberi Crude Fucoidan dari Rumput Laut Coklat (Sargassum Polycystum) yang Diinduksi Diet Tinggi Lemak
}

\section{(Comparison of Lipid Profile and Determination of Atherogenic Index in White Rats were Given Crude Fucoidan from Brown Seaweed (Sargassum Polycystum) that Induced High-Fat Diet)}

\author{
JULIANA A PURUKAN ${ }^{1 *}$, KUSMARDI ${ }^{2}$, BAMBANG PONCO PRIOSOERYANTO ${ }^{3}$, DIAN RATIH \\ LAKSMITAWATI $^{1}$, SYAMSUDIN ABDILLAH ${ }^{1}$ \\ ${ }^{1 *}$ Fakultas Farmasi Universitas Pancasila \\ ${ }^{2}$ Bagian Patologi Klinik, Fakultas Kedokteran Universitas Indonesia
}

Diterima 26 November 2018, Disetujui 22 Maret 2019

\begin{abstract}
Abstrak: Penyakit jantung koroner adalah penyebab kematian nomor satu di dunia. Salah satu faktor risiko penyakit jantung koroner adalah aterosklerosis. Penyebab utamanya adalah tingginya konsumsi lemak jenuh dan kolesterol mengakibatkan peningkatan kadar kolesterol dan LDL. Rumput laut coklat (Sargassum polycystum) merupakan salah satu tanaman yang menghasilkan aktivitas farmakologik yaitu sebagai anti aterosklerotik dengan kandungan kimia yang berpotensi adalah fucoidan. Penelitian ini bertujuan untuk mengetahui efektivitas crude fucoidan dalam menurunkan kadar kolesterol, LDL, TG, menaikkan kadar HDL dan Indeks Aterogenik. Tahapan optimasi digunakan 5 ekor hewan uji tikus untuk melihat pengaruh komposisi diet tinggi lemak yang diberikan terhadap profil lipid. Sedangkan pada tahap pengujian digunakan 30 ekor hewan uji yang dibagi menjadi 6 kelompok untuk melihat pengaruh diet tinggi lemak dan crude fucoidan yang diberikan terhadap profil lipid. Pemeriksaan profil lipid dilakukan sebanyak tiga kali yaitu pada hari ke-0, ke-14 dan hari ke-36 setelah itu dihitung indeks aterogeniknya. Pada hari ke-36 hewan uji di anestesi dan dinekropsi untuk selanjutnya dilakukan pengambilan darah melalui organ jantung.

Hasil penelitian menunjukkan bahwa crude fucoidan dosis $200 \mathrm{mg}$ dapat menurunkan kadar kolesterol total, LDL, TG, menaikkan kadar HDL dan memiliki penurunan indeks aterogenik serum tikus secara bermakna dibandingkan dengan dosis $100 \mathrm{mg}$ dan $50 \mathrm{mg}$, tetapi tidak berbeda bermakna dengan kontrol positif atorvastatin dosis $10 \mathrm{mg}$.
\end{abstract}

Kata kunci: Crude fucoidan, atorvastatin, diet tinggi lemak, kolesterol total, Low Density Lipoprotein (LDL), High Density Lipoprotein (HDL), Trigliserida, indeks aterogenik.

\begin{abstract}
Coronary heart disease is the number one cause of death in the world. One risk factor for coronary heart disease is atherosclerosis. The main cause is the high consumption of saturated fats and cholesterol resulting in increased cholesterol and LDL levels. Brown seaweed (Sargassum polycystum) is one of the plants that produces pharmacological activity which is as anti-atherosclerotic with the potential chemical content is fucoidan. The aim of this research is to know the effectiveness of crude fucoidan in decreasing total cholesterol, LDL, TG, increasing HDL levels and atherogenic index. In the optimization phase, 5 rat test animals were used to see the effect of the composition of a high-fat diet given on lipid profiles. While in the testing phase 30 test animals were divided into 6 groups to see the effect of a high-fat and crude fucoidan diet given to lipid profiles. Examination of lipid profiles was carried out three times, namely on the 0th, 14th and 36th days, after that the atherogenic index is calculated. On the 36th day the test, rats were anesthetized and necropsy for subsequent blood collection through the heart organ. The results showed that $200 \mathrm{mg}$ crude fucoidan dose could significantly decreasing total cholesterol, LDL, TG, increased HDL levels and significantly decreased the atherogenic index of rat serum compared to the dosages of $100 \mathrm{mg}$ and $50 \mathrm{mg}$, but did not differ significantly from the positive control at $10 \mathrm{mg}$ atorvastatin.
\end{abstract}

Keywords: Crude fucoidan, atorvastatin, high-fat diet, total cholesterol, Low Density Lipoprotein (LDL), High Density Lipoprotein (HDL), Triglycerides, atherogenic index.

\footnotetext{
*Penulis korespondensi, Hp. 081280825215
} 


\section{PENDAHULUAN}

PERKEMBANGAN zaman dan arus globalisasi telah membawa banyak perubahan terhadap gaya hidup manusia dan pola makan telah memicu timbulnya berbagai gangguan kesehatan seperti tingginya kadar kolesterol, diabetes mellitus, tingginya kadar asam urat dan penyakit kardiovaskular salah satunya penyakit jantung koroner ${ }^{(1)}$. Penyakit jantung koroner adalah penyebab kematian nomor satu di dunia. Pada tahun 2017, Badan Kesehatan Dunia (WHO) mencatat ada sekitar $45,1 \%$ penduduk dunia meninggal akibat penyakit jantung koroner ${ }^{(2)}$. Sedangkan, berdasarkan diagnosis dokter prevalensi penyakit jantung koroner di Indonesia pada tahun 2017 sebesar 12,7\%. Hasil riset kesehatan dasar ini menunjukkan penyakit jantung koroner berada pada posisi ketujuh tertinggi penyakit tidak menular di Indonesia(3). Salah satu faktor risiko penyakit jantung koroner (PJK) adalah aterosklerosis, yaitu suatu keadaan pada arteri besar dan kecil yang ditandai oleh endapan lemak, trombosit, makrofag dan leukosit di seluruh lapisan tunika intima dan akhirnya ke tunika media ${ }^{(4)}$. Penyebab utama aterosklerosis adalah lipoprotein dan hiperlipidemia dimana tingginya konsumsi lemak jenuh dan kolesterol menyebabkan peningkatan kadar kolesterol dan lipoprotein densitas rendah (Low Density Lipoprotein $=\mathrm{LDL})^{(1)}$.

Kadar LDL yang tinggi menyebabkan meningkatnya jumlah partikel LDL yang masuk ke sub intima pembuluh darah di daerah predileksi. LDL kemudian ditangkap makrofag melalui pengikatan pada reseptor LDL, dan karena kapasitas makrofag untuk menangkap LDL terbatas, maka jumlah partikel LDL sub intima meningkat. Akibatnya, terdapat sejumlah sisa partikel LDL yang akan dioksidasi oleh makrofag dan otot polos, menghasilkan ion mo-LDL (midly oxidized LDL) atau LDL-oks. LDLoks kemudian ditangkap oleh makrofag melalui reseptor ScR (scavenger-receptor) secara terus menerus dan berubah menjadi sel busa. LDL-oks bersifat sitotoksik sehingga menimbulkan kematian sel busa dan terjadi penumpukan lemak (kolesterol) ekstrasel. Kadar LDL yang tinggi dan penebalan dinding aorta abdominalis merupakan penyebab primer aterosklerosis ${ }^{(5,6)}$. Berbagai upaya dilakukan untuk mengobati aterosklerosis ini salah satunya dengan statin, salah satu obat penurun lipid paling efektif untuk menurunkan kolesterol LDL dan terbukti aman atau tanpa efek samping yang berarti. Selain berfungsi untuk menurunkan kolesterol LDL, statin juga mempunyai efek meningkatkan High Density Lipoprotein (HDL) dan menurunkan trigliserida
(TG). Cara kerja statin adalah dengan menghambat kerja enzim 3-hydroxy-3-methylglutaryl coenzim A-reductase inhibitor (HMG-CoA reduktase). Efeknya dalam regulasi Cholesteryl Ester Transfer Protein (CETP) menyebabkan penurunan konsentrasi kolesterol LDL dan Very Low Density Lipoprotein $(\mathrm{VLDL})^{(7)}$.

Atorvastatin sebagai salah satu obat golongan statin memiliki efek pleiotropic yang lebih baik dibandingkan golongan statin lain seperti adanya efek menstabilkan plague, penurunan kasus terjadinya serangan iskemik stroke berulang dan menghambat pembentukan aterosklerosis ${ }^{(8)}$. Namun, adanya penggunaan statin dapat menyebabkan sakit kepala, efek pada saluran cerna meliputi abdomen, flatulens, konstipasi, diare, mual dan muntah serta ruam kulit dan reaksi hipersensitivitas yang telah dilaporkan meskipun jarang terjadi ${ }^{(9)}$.

Efek samping yang membahayakan menjadi pendorong untuk mencari alternatif yang lebih baik dengan mengembangkan penggunaan obat tradisional untuk menangani berbagai macam penyakit. Salah satu jenis tumbuhan yang dapat digunakan sebagai obat yaitu rumput laut. Rumput laut merupakan kelompok tumbuhan yang berklorofil yang terdiri dari satu atau banyak sel dan berbentuk koloni apabila ditinjau secara biologi. Rumput laut mengandung bahanbahan organik seperti polisakarida, hormon, vitamin, mineral, dan juga senyawa bioaktif ${ }^{(10)}$. Alga coklat Sargassum sp. sangat melimpah serta tersebar luas di perairan Indonesia. Sargassum sp. mengandung bahan alginat dan iodin yang digunakan pada industri makanan, farmasi, kosmetik dan tekstil. Selain itu, Sargassum sp. mengandung senyawa-senyawa aktif steroida, alkaloida, fenol, dan triterpenoid yang berfungsi sebagai antibakteri, antivirus, dan anti jamur $^{(11)}$. Di Indonesia terdapat 12 jenis Sargassum yang sudah diteliti yaitu $S$. duplicatum, S. hystrix, S. echinocarpum, S. binderi Sonder, S. gracilinum, S. crassifolium, S. obtusifolium, S. microphylum, S. vulgare, S. polyceratium, S. aquofilum dan $S$. polycystum $^{(12)}$

S. polycystum merupakan salah satu rumput laut yang banyak mengandung bahan kimia serta berpotensi untuk dimanfaatkan dan dikembangkan. Kandungan kimia dari S. polycystum diantaranya yaitu protein, vitamin $\mathrm{C}$, tanin, iodin, fenol, alginat dan fucoidan yang dapat digunakan sebagai bahan pangan, obat-obatan, kosmetik dan tekstil ${ }^{(11)}$. Pada penelitian awal ekstrak rumput laut coklat (S. polycystum) dibuat sediaan nanopartikel dan di uji efek anti platelet secara in vivo dan diketahui bahwa sediaan ekstrak rumput laut coklat $(S$. polycystum) dapat memperpanjang waktu pendarahan dan waktu koagulasi pada tikus ${ }^{(13)}$. 
Ekstrak kasar fucoidan pada alga coklat S. polycystum juga memiliki aktivitas antikanker terhadap viabilitas sel $\mathrm{HeLa}^{(14)}$.

Berdasarkan latar belakang diatas, maka dilakukan penelitian tentang perbandingan profil lipid pada tikus putih yang diberi crude fucoidan dari ekstrak rumput laut coklat $S$. polycystum dan statin yang di induksi diet tinggi lemak. Penelitian ini menggunakan tikus putih (Rattus norvegicus) jantan galur Sprague Dawley (SD) sebagai model hewan uji yang diberi diet tinggi lemak selama 35 hari. Pemilihan hewan uji menggunakan tikus putih jantan, karena pada tikus betina memproduksi hormon estrogen yang dapat mempengaruhi metabolisme lemak dan kolesterol sehingga akan mempengaruhi profil lipid(1).

\section{BAHAN DAN METODE}

BAHAN. Crude fucoidan dari rumput laut coklat (Sargassum polycystum), pakan diet tinggi lemak dan pakan diet normal, Na-CMC $0.1 \%$, Atorvastatin $10 \mathrm{mg}$, ketamine xylazine, $\mathrm{NaCl}$, aquadest, alkohol.

ALAT. Alat Pemeliharaan Hewan Uji. Kandang hewan, wadah untuk pakan, wadah air minum.

Alat Pemeriksaan Profil Lipid.Tabung hematokrit, pipet mikro (Dragon SurePette), pipette tip (Citotest), centrifuge (TD4A-2), tabung eppendrof, vaculab (OneMed), respons ${ }^{\circledR} 901$.

Alat Bedah Tikus. Papan wax, jarum, pinset, pinset chirurgis, gunting, scalpel, penyemprot alkohol. Lain-lain: timbangan hewan uji, gelas beker, erlenmeyer, gelas ukur, batang pengaduk, sonde lambung tikus.

Hewan Uji. Hewan uji yang akan digunakan dalam tahapan optimasi pada penelitian ini adalah tikus (Rattus norvegicus) putih galur Sprague Dawley (SD) (5 ekor tikus jantan) umur 2 sampai 2.5 bulan dengan bobot 100-150 g.

METODE PENELITIAN. Persiapan Hewan uji Tikus yang diikutsertakan dalam percobaan adalah tikus yang sehat dengan ciri-ciri mata merah jernih, bulu tidak berdiri, dan aktif. Tikus ditimbang beratnya secara berkala untuk mengontrol berat badan. Untuk membedakan masing-masing kelompok perlakuan, dilakukan penandaan tikus menggunakan larutan asam pikrat yang dioleskan pada bagian tubuh tikus.

Induksi Diet Tinggi Lemak. Tahap Orientasi. Sebanyak 5 ekor tikus putih jantan yang sebelumnya telah diaklimatisasi selama 1 minggu, dibagi menjadi 2 kelompok, yaitu 1 ekor sebagai kontrol normal dan 4 ekor lainnya sebagai kontrol negatif (pemberian pakan diet tinggi lemak). Lima ekor tikus dilakukan pemeriksaan profil lipid (kolesterol total, LDL, HDL dan TG) pada hari ke-0, ke-14 dan ke-36. Pada hari ke-36, ke lima ekor tikus tersebut di anestesi dengan ketamine xylazine dan dinekropsi untuk diambil darah melalui jantung.

Tahap Pengujian. Sebanyak 30 ekor tikus putih jantan yang sebelumnya telah diaklimatisasi selama 1 minggu, dibagi menjadi 6 kelompok, yaitu:

Kelompok I : kontrol normal, diberi pakan diet normal.

Kelompok II : kontrol negatif, diberi pakan diet tinggi lemak.

Kelompok III : kontrol positif, diberi pakan diet tinggi lemak dan atorvastatin 10 $\mathrm{mg} / \mathrm{kg} \mathrm{BB}$ dalam larutan $\mathrm{Na}-\mathrm{CMC}$ $0,1 \%$.

Kelompok IV : diberi pakan diet tinggi lemak dan crude fucoidan dosis $50 \mathrm{mg} / \mathrm{kg} \mathrm{BB}$ dalam larutan $\mathrm{Na}-\mathrm{CMC} 0,1 \%$.

Kelompok V : diberi pakan diet tinggi lemak dan crude fucoidan dosis $100 \mathrm{mg} / \mathrm{kg} \mathrm{BB}$ dalam larutan $\mathrm{Na}-\mathrm{CMC} \mathrm{0,1 \% .}$

Kelompok VI : diberi pakan diet tinggi lemak dan crude fucoidan dosis $200 \mathrm{mg} / \mathrm{kg} \mathrm{BB}$ dalam larutan $\mathrm{Na}-\mathrm{CMC} 0,1 \%$.

Pengambilan darah pada hari ke-0, ke-14 dan ke-36. Pada hari ke-0 dan ke-14 melalui sinus orbitalis. Pada hari ke-36 tikus tersebut di anestesi dengan ketamine xylazine 0,2 mL IP dan dinekropsi untuk diambil darah melalui jantung.

Pemberian Pakan Diet Tinggi Lemak dan Pakan Diet Normal. Komposisi pakan diet normal dan diet tinggi lemak yang akan diberikan pada hewan uji terdiri dari vitamin, selulosa, kolesterol, lemak hewani, sukrosa, tepung jagung dan kasein seperti yang dijabarkan dalam Tabel 1.

Tabel 1. Komposisi pakan diet tinggi lemak dan pakan diet normal ${ }^{16}$.

\begin{tabular}{lcc}
\hline \multirow{2}{*}{ Bahan } & \multicolumn{2}{c}{ Jumlah (\%) } \\
\cline { 2 - 3 } & $\begin{array}{c}\text { Pakan diet } \\
\text { normal }\end{array}$ & $\begin{array}{c}\text { Pakan diet } \\
\text { tinggi lemak }\end{array}$ \\
\hline Vitamin & 5 & 5 \\
Selulosa & 5 & 5 \\
Kolesterol & 0,5 & 0,5 \\
Lemak hewani & 4,5 & 20 \\
Sukrosa & 15 & 20 \\
Tepung jagung & 34,5 & 40 \\
Kasein & 20 & 25 \\
\hline
\end{tabular}


Pemeriksaan Profil Lipid dan Penentuan Indeks Aterogenik. Sampel darah tikus putih jantan pada hari ke-0 dan ke-14 diambil menggunakan tabung hematrokrit melalui sinus orbitalis sebanyak $1 \mathrm{~mL}$. Darah yang keluar ditampung dengan vaculab ukuran $3 \mathrm{ml}$ kemudian di sentrifugasi dengan kecepatan 3000 rpm selama 10 menit. Hari ke-36 tikus dianestesi menggunakan ketamine xylazine 0,2 $\mathrm{mL}$ dan di nekropsi. Darah diambil pada organ jantung menggunakan jarum disposable $5 \mathrm{~mL}$ dan ditampung dalam vaculab $3 \mathrm{~mL}$ kemudaian disentrifugasi dengan kecepatan $300 \mathrm{rpm}$ selama 10 menit. Serum kemudian dikumpulkan menggunakan micro pipet dan dimasukkan kedalam tabung eppendrof untuk selanjutnya diperiksa menggunakan alat respons ${ }^{\circledR} 901$. Indeks aterogenik dihitung menggunakan rumus ${ }^{(17)}$ :

$$
\text { Indeks Aterogenik }=\frac{\text { Kolesterol Total - HDL }}{\text { HDL }}
$$

\section{HASIL DAN PEMBAHASAN}

Tahapan Optimasi. Pemeriksaan Prodil Lipid. Hasil penelitian kadar kolesterol total, HDL, LDL dan Trigliserida pada hewan uji tikus jantan galur SD dilakukan analisis deskriptif dan dimasukkan dalam Tabel 2. Dalam Tabel 2. ditunjukkan bahwa kadar kolesterol serum 1 ekor tikus jantan Sprague dawley pada hari ke-0 dan ke-14 masih dalam angka normal, dimana diketahui nilai normal kadar kolesterol total serum yaitu $10-54 \mathrm{mg} / \mathrm{dL}^{(18)}$, namun terjadi peningkatan pada hari ke-36 untuk kolesterol total menjadi $59 \mathrm{mg} / \mathrm{dl}$. Nilai LDL serum terjadi peningkatan pada hari ke-36, dibandingkan dengan nilai normal, yaitu: 7-27.2 mg/dL ${ }^{(19)}$. Nilai HDL dan trigliserida serum pada hari ke-0, ke-14 dan ke-36 masih dalam nilai normal masing-masing yaitu $\geq 35$ $\mathrm{mg} / \mathrm{dL}^{(20)}$ dan 26-145 mg/dL ${ }^{(21)}$.

Kurva kadar profil lipid serum ditunjukkan dalam Gambar 1. Pada Tabel 3. menunjukkan bahwa nilai

Tabel 2. Kadar profil lipid serum tikus (mg/dL) kontrol normal.

\begin{tabular}{lccc}
\hline \multicolumn{1}{c}{ Hewan uji 1 } & $\begin{array}{c}\text { Hari } \\
\text { ke-0 }\end{array}$ & $\begin{array}{c}\text { Hari } \\
\text { ke-14 }\end{array}$ & $\begin{array}{c}\text { Hari } \\
\text { ke-36 }\end{array}$ \\
\hline $\begin{array}{l}\text { Kolesterol total } \\
\text { (mg) }\end{array}$ & 48 & 50 & 52 \\
LDL (mg) & 10 & 12 & 14 \\
HDL (mg) & 36 & 38 & 37 \\
Trigliserida (mg) & 80 & 91 & 101 \\
\hline
\end{tabular}

rata-rata nilai profil lipid hewan uji 2 sampai 5 pada hari ke-0 masih berada pada batas normal. Nilai profil lipid (kolesterol total, LDL dan TG) terjadi peningkatan saat pemeriksaan pada hari ke-14 dan ke-36. Sedangkan nilai HDL pada pemeriksaan hari ke-14 dan ke-36 terjadi penurunan berbeda dengan 1 ekor hewan uji tikus yang hanya diberi pakan diet normal sebagaimana ditunjukkan dalam Gambar 2. Pada Gambar 2 memperlihatkan bahwa komposisi diet tinggi lemak yang digunakan pada penelitian ini dapat

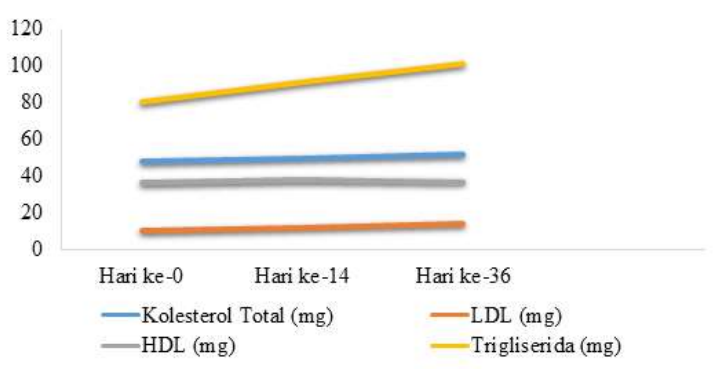

Gambar 1. Kurva kadar profil lipid serum (mg/dL) hewan uji tikus jantan galur SD (diet normal) tahap optimasi pada hari ke-0, ke-14 dan ke-36.

meningkatkan nilai kolesterol total, LDL, TG dan dapat menurunkan nilai HDL serum darah tikus pada hari ke-14 dan berlanjut sampai hari ke-36. Pada uji kruskal wallis juga menunjukkan perbedaan yang nyata dari 4 ekor hewan uji yang diberikan pakan diet tinggi lemak dan yang tidak diberikan pakan diet tinggi lemak dengan nilai $\mathrm{p}<0.05$. Pada penelitian yang dilakukan oleh Isdadiyanto S (2015), diketahui bahwa pemberian komposisi pakan diet tinggi lemak yang menggunakan campuran vitamin, selulosa, kolesterol, lemak, karbohidrat, sukrosa dan kasein dapat meningkatkan kadar profil lipid dan meningkatkan kadar apoprotein A dan apoprotein B16. Sedangkan menurut penelitian yang dilakukan oleh Ismawati et al (2017) diketahui bahwa pemberian vitamin D3, karbohidrat dan lemak pada berbagai konsentrasi dapat mengakibatkan peningkatan kadar LDL sebagai penyebab terjadinya aterosklerosis $^{(2)}$. Pada komposisi pakan diet tinggi lemak menggunakan vitamin D3 untuk induksi aterosklerosis, penambahan vitamin D3 dilakukan untuk meningkatkan klasifikasi pembuluh darah dan stimulasi proliferasi sel otot polos pembuluh darah sehingga mengakibatkan terbentuknya penebalan pada fibromuskular intimal ${ }^{(22)}$. Sementara penggunaan lemak yaitu lemak jenuh yang memungkinkan peningkatan absorpsi kolesterol dalam makanan atau mengurangi sekresi dalam feses. Lemak jenuh dapat merangsang produksi kolesterol berlebihan dalam hati atau memudahkan penimbunannya di dalam darah ${ }^{(23)}$. 
Penggunaan karbohidrat pada komposisi diet tinggi lemak dikarenakan adanya konsumsi karbohidrat yang berlebihan dapat memicu penyakit jantung pada seseorang. Karbohidrat berlebih bisa meningkatkan kadar glukosa di dalam darah dan berakibat pada resiko penyakit jantung yang semakin tinggi. Konsumsi tinggi karbohidrat cenderung meningkatkan kadar trigliserida dan menurunkan kadar kolesterol HDL. Senyawa trigliserida yakni jenis lemak yang biasanya dijumpai di dalam darah yang mengandung glukosa lebih. Kadar trigliserida tinggi dan HDL rendah maka akan berpengaruh pada aterosklerosis dan berimbas pada penyakit jantung sehingga dapat terjadi serangan jantung yang mendadak ${ }^{(24)}$.

Penentuan Indeks Aterogenik pada Tahapan Optimasi. Pada Tabel 4. menunjukkan bahwa indeks aterogenik pada 4 ekor tikus putih jantan yang diberi diet tinggi lemak sangat tinggi jika dibandingkan dengan 1 ekor tikus putih jantan yang diberi diet normal. Terjadi peningkatan rata-rata indeks aterogenik pada tikus yang diinduksi diet tinggi lemak pada hari ke 14 sebanyak 1,11 menjadi 1,93 pada hari ke-36. Hal ini menunjukkan bahwa komposisi diet tinggi lemak yang digunakan pada tahapan optimasi dapat mengakibatkan terjadinya aterosklerosis jika dilihat dari indeks aterosklerosis yang diperoleh.

Tahapan Pengujian. Pemeriksaan Kolesterol Total. Rata-rata kadar kolesterol total pada tikus dengan kontrol negatif (tikus yang diberikan pakan

Tabel 4. Rata-rata Indeks Aterogenik tikus tahapan optimasi pada hari ke-0, ke-14 dan ke-36.

Indeks Aterogenik

\begin{tabular}{lccc}
\hline & \multicolumn{3}{c}{ Indeks Aterogenik } \\
\multirow{2}{*}{ Hewan Uji } & \multicolumn{3}{c}{ Hari ke- } \\
\cline { 2 - 4 } & 0 & 14 & 36 \\
\hline Diet normal & 0,38 & 0,36 & 0,48 \\
Diet tinggi lemak & 0,31 & 1,10 & 1,95 \\
\hline
\end{tabular}

diet tinggi lemak) pada hari ke-14 sebesar $65,6 \mathrm{mg} / \mathrm{dL}$ dan pada hari ke-36 sebesar 78,2 mg/dL lebih tinggi dibandingkan dengan kelompok I yang diberi pakan diet normal. Sedangkan rata-rata kadar kolesterol total kelompok VI (tikus yang diberikan pakan diet tinggi lemak dan crude fucoidan dosis $200 \mathrm{mg} / \mathrm{kg} \mathrm{BB}$ ) saat pemeriksaan pada hari ke-36 sebesar $65 \mathrm{mg} / \mathrm{dL}$ lebih besar dibandingkan kelompok IV dan V, namun

Tabel 3. Rata-rata kadar profil lipid serum tikus (mg/dL) pada tahap optimasi sebelum dan setelah pemberian diet tinggi lemak.

\begin{tabular}{|c|c|c|c|c|c|c|c|c|c|c|c|c|}
\hline \multirow[b]{2}{*}{$\begin{array}{c}\text { Hewan uji } \\
\text { (Tikus II-IV) }\end{array}$} & \multicolumn{3}{|c|}{ Kolesterol total } & \multicolumn{3}{|c|}{ LDL } & \multicolumn{3}{|c|}{ HDL } & \multicolumn{3}{|c|}{ Trigliserida } \\
\hline & \multicolumn{3}{|c|}{ Hari ke- } & \multicolumn{3}{|c|}{ Hari ke- } & \multicolumn{3}{|c|}{ Hari ke- } & \multicolumn{3}{|c|}{ Hari ke- } \\
\hline Median & 53,5 & 61 & 73,5 & 10 & 22 & 29 & 40,5 & 29 & 25 & 90,5 & 102 & 116,5 \\
\hline
\end{tabular}



Gambar 2. Kurva kadar profil lipid serum $(\mathrm{mg} / \mathrm{dL})$ rata-rata hewan uji tikus jantan galur SD (diet tinggi lemak) tahap optimasi pada hari ke-0, ke-14 dan ke-36. lebih kecil dibandingkan kelompok III yang diberi atorvastatin dosis $10 \mathrm{mg} / \mathrm{kg} \mathrm{BB}$ (Gambar 3).

Pemeriksaan High Density Lipoprotein (HDL). Pada Gambar 4 menunjukkan rata-rata kadar kolesterol HDL kelompok VI (tikus yang diberikan pakan diet tinggi lemak dan crude fucoidan dosis $200 \mathrm{mg} / \mathrm{kg} \mathrm{BB}$ ) saat pemeriksaan pada hari ke-36 mengalami kenaikkan yaitu 47,8 mg/dL lebih besar dibandingkan kelompok IV yang diberikan crude fucoidan dosis $50 \mathrm{mg}$ dan kelompok $\mathrm{V}$ yang diberikan crude fucoidan dosis $100 \mathrm{mg}$ namun lebih kecil dibandingkan kelompok III yang diberi atorvastatin dosis $10 \mathrm{mg} / \mathrm{kg}$ BB yang mengalami kenaikkan kadar kadar HDL rata-rata sebesar 51,2 mg/dL. Sedangkan 
kadar HDL rata-rata kelompok I yang diberikan pakan diet normal tidak mengalami penurunan kadar HDL yang signifikan berbeda dengan kelompok II yang diberikan pakan diet tinggi lemak yang mengalami rata-rata penurunan pada hari ke-36 sebesar 37,4 $\mathrm{mg} / \mathrm{dL}$.

Pemeriksaan Low Density Lipoprotein (LDL). Pada Gambar 5. menunjukkan rata-rata kadar kolesterol LDL kelompok VI (tikus yang diberikan

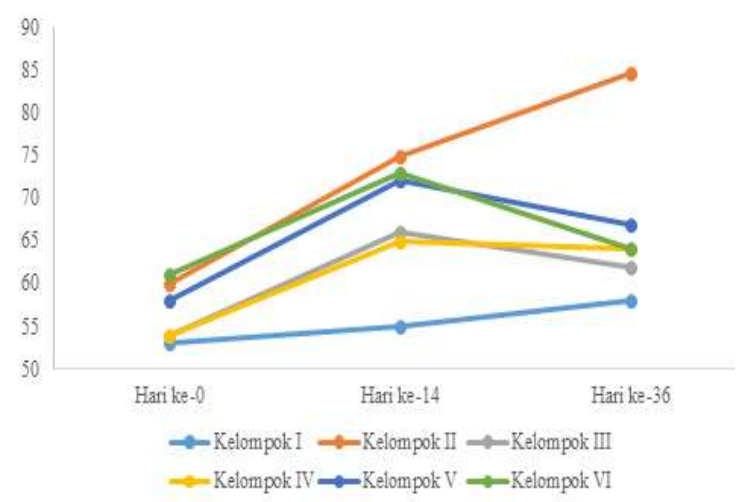

Gambar 3. Kurva kadar kolesterol total (mg/dL) rata-rata hewan uji tikus jantan galur SD tahap pengujian pada hari ke-0, ke-14 dan ke-36.

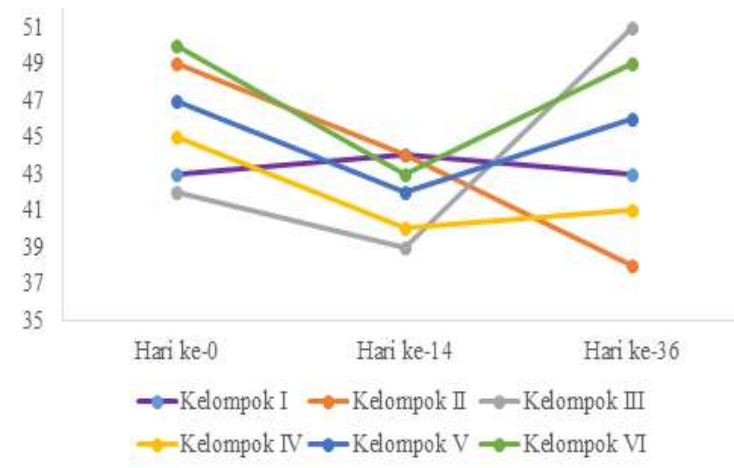

Gambar 4. Kurva kadar kolesterol HDL (mg/dL) rata-rata hewan uji tikus jantan galur SD tahap pengujian pada hari ke-0, ke-14 dan ke-36.

pakan diet tinggi lemak dan crude fucoidan dosis $200 \mathrm{mg} / \mathrm{kg} \mathrm{BB}$ ) saat pemeriksaan pada hari ke-36 mengalami penurunan yaitu $22,2 \mathrm{mg} / \mathrm{dL}$ lebih besar dibandingkan kelompok IV yang diberikan crude fucoidan dosis $50 \mathrm{mg}$ dengan rata-rata penurunan kadar sebesar 28,6 mg/dL dan kelompok $\mathrm{V}$ yang diberikan crude fucoidan dosis $100 \mathrm{mg}$ dengan rata-rata penurunan kadar sebesar $24 \mathrm{mg} / \mathrm{dL}$ namun lebih kecil dibandingkan kelompok III yang diberi atorvastatin dosis $10 \mathrm{mg} / \mathrm{kg} \mathrm{BB}$ yang mengalami rata-rata penurunan kadar LDL sebesar 17,8 mg/dL.
Sedangkan rata-rata kenaikan kadar LDL kelompok I yang diberi pakan diet normal pada saat pemeriksaan hari ke-36 hanya sebesar $12,8 \mathrm{mg} / \mathrm{dL}$, berbeda dengan rata-rata kenaikan kadar LDL kelompok II yang diberi pakan diet tinggi lemak saat pemeriksaan hari ke-36 yaitu sebesar $37,2 \mathrm{mg} / \mathrm{dL}$.

Pemeriksaan Trigliserida. Pada Gambar 6. menunjukkan rata-rata kadar trigliserida kelompok VI (tikus yang diberikan pakan diet tinggi lemak dan

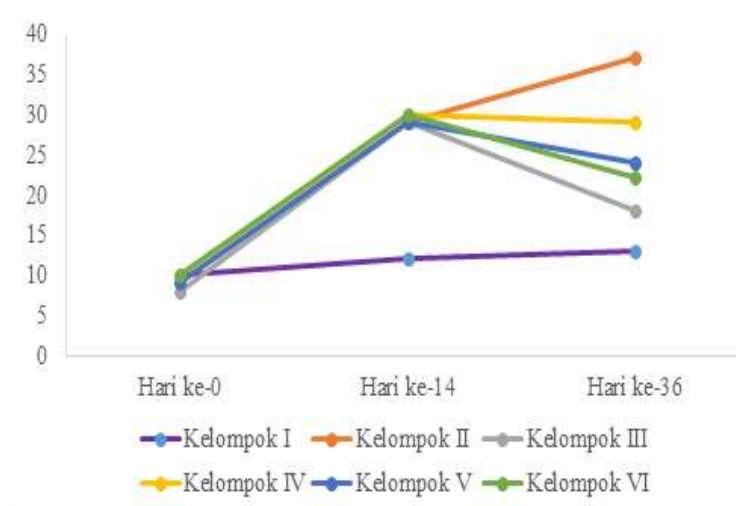

Gambar 5. Kurva kadar kolesterol LDL (mg/dL) rata-rata hewan uji tikus jantan galur SD tahap pengujian pada hari ke-0, ke-14 dan ke-36.

crude fucoidan dosis $200 \mathrm{mg} / \mathrm{kg} \mathrm{BB}$ ) saat pemeriksaan pada hari ke-36 mengalami penurunan yaitu 87,4 $\mathrm{mg} / \mathrm{dl}$ lebih besar dibandingkan kelompok IV yang diberikan crude fucoidan dosis $50 \mathrm{mg}$ dengan rata-rata penurunan kadar sebesar 95,6 mg/dL dan kelompok V yang diberikan crude fucoidan dosis $100 \mathrm{mg}$ dengan rata-rata penurunan kadar sebesar 97,8 mg/dL namun lebih kecil dibandingkan kelompok III yang diberi atorvastatin dosis $10 \mathrm{mg} / \mathrm{kg}$ BB yang mengalami ratarata penurunan kadar trigliserida sebesar 82,2 mg/dL. Sedangkan rata-rata kenaikan kadar TG kelompok I yang diberi pakan diet normal pada saat pemeriksaan hari ke-36 hanya sebesar $80 \mathrm{mg} / \mathrm{dL}$, berbeda dengan rata-rata kenaikan kadar LDL kelompok II yang diberi pakan diet tinggi lemak saat pemeriksaan hari ke-36 yaitu sebesar 101,4 mg/dL. Berdasarkan uji Kruskal Wallis yang dilakukan terhadap kadar profil lipid dalam kelompok perlakuan, didapat bahwa kadar profil lipid kelompok II berbeda bermakna $(p<0.05)$ dengan semua kelompok perlakuan dan kelompok III berbeda bermakna dengan kelompok IV yang diberi crude fucoidan dosis $50 \mathrm{mg}$ dan kelompok $\mathrm{V}$ yang diberi crude fucoidan dosis $100 \mathrm{mg}$ namun tidak berbeda bermakna dengan kelompok VI yang diberi crude fucoidan dosis $200 \mathrm{mg}$ ( $\mathrm{p}>0,05)$.

Penentuan Indeks Aterogenik. Indeks aterogenik merupakan indikator untuk mengetahui resiko 
aterosklerosis yang merupakan penyebab utama

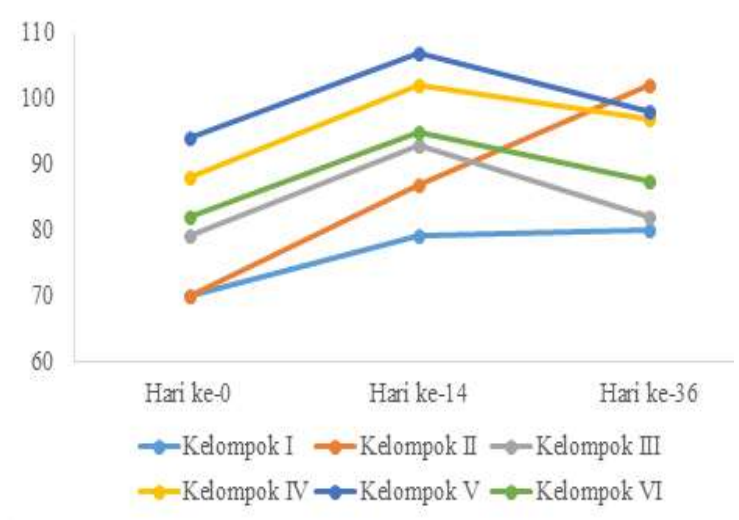

Gambar 6. Kurva kadar trigliserida (mg/dL) rata-rata hewan uji tikus jantan galur SD tahap pengujian pada hari ke0, ke-14 dan ke-36.

penyakit jantung koroner ${ }^{(17)}$. Tabel 5. menunjukkan bahwa indeks aterogenik tikus yang hanya diberi diet tinggi lemak (kontrol negatif) sangat tinggi dibandingkan dengan tikus yang diberi diet normal dan perlakuan berupa atorvastatin sebagai kontrol positif dan crude fucoidan pada hari ke-15 sampai hari ke-35.

Kelompok tikus putih jantan yang diberi diet tinggi lemak memiliki indeks aterogenik tertinggi pada hari ke 36 sebesar 1,23 dibandingkan dengan tikus putih jantan yang diberi pakan diet normal sebesar 0,42 . Sementara kelompok tikus putih jantan yang diberi pakan diet tinggi lemak dan atorvastatin 10 mg memiliki indeks aterogenik yang menurun sangat signifikan pada hari ke-36 yaitu dari 0,69 menjadi 0,21 . Diikuti kelompok dengan pemberian diet tinggi lemak dan crude fucoidan dosis $200 \mathrm{mg}$ yang memiliki indeks aterogenik dari 0,69 menjadi 0,30 (Gambar 7). Hal ini menunjukkan bahwa crude fucoidan efektif untuk terapi anti aterogenik.

Kadar LDL yang tinggi dalam darah dapat menyebabkan meningkatnya jumlah partikel LDL yang masuk ke sub intima pembuluh darah di daerah predileksi. LDL kemudian ditangkap makrofag melalui pengikatan pada reseptor LDL, dan karena kapasitas makrofag untuk menangkap LDL terbatas,

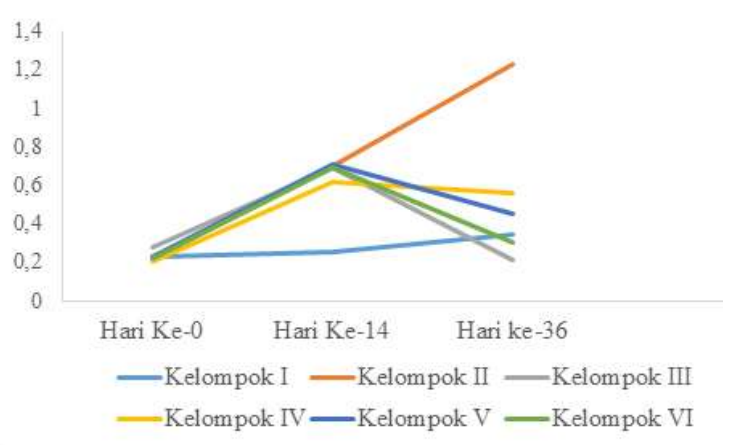

Gambar 7. Kurva Indeks Aterogenik rata-rata hewan uji tikus jantan galur SD tahap pengujian hari ke-0, ke-14 dan ke-36.

Tabel 5. Rata-rata Indeks Aterogenik tikus tahapan pengujian pada hari ke-0, ke-14 dan ke-36.

\begin{tabular}{|c|c|c|c|}
\hline \multirow{2}{*}{ Hewan uji } & \multicolumn{3}{|c|}{ Indeks Aterogenik (IA) } \\
\hline & Hari ke-0 & Hari ke-14 & Hari ke-36 \\
\hline $\begin{array}{l}\text { Kelompok I } \\
\text { (Diet normal) }\end{array}$ & 0,23 & 0,25 & 0,34 \\
\hline $\begin{array}{l}\text { Kelompok II } \\
\text { (Diet tinggi lemak) }\end{array}$ & 0,22 & 0,70 & 1,23 \\
\hline $\begin{array}{c}\text { Kelompok III } \\
\text { (Atorvastatin } 10 \mathrm{mg} \text { ) }\end{array}$ & 0,28 & 0,69 & 0,21 \\
\hline $\begin{array}{c}\text { Kelompok IV } \\
\text { (Crude fucoidan } 50 \mathrm{mg} \text { ) }\end{array}$ & 0,2 & 0,62 & 0,56 \\
\hline $\begin{array}{c}\text { Kelompok V } \\
\text { (Crude fucoidan } 100 \mathrm{mg} \text { ) }\end{array}$ & 0,23 & 0,71 & 0,45 \\
\hline $\begin{array}{c}\text { Kelompok VI } \\
\text { (Crude fucoidan } 200 \mathrm{mg} \text { ) }\end{array}$ & 0,22 & 0,69 & 0,30 \\
\hline
\end{tabular}


maka jumlah partikel LDL sub intima meningkat. Akibatnya, terdapat sejumlah sisa partikel LDL yang akan dioksidasi oleh makrofag dan otot polos, menghasilkan ion mo-LDL (midly oxidized LDL) atau LDL-oks. LDL-oks kemudian ditangkap oleh makrofag melalui reseptor ScR (scavenger-receptor) secara terus menerus dan berubah menjadi sel busa. LDL-oks bersifat sitotoksik sehingga menimbulkan kematian sel busa dan terjadi penumpukan lemak (kolesterol) ekstrasel. Kadar LDL yang tinggi dan penebalan dinding aorta abdominalis merupakan penyebab primer aterosklerosis ${ }^{(5,6)}$. S. polycystum merupakan salah satu rumput laut yang banyak mengandung bahan kimia serta berpotensi untuk dimanfaatkan dan dikembangkan. Kandungan kimia dari S. polycystum diantaranya yaitu protein, vitamin $\mathrm{C}$, tanin, iodin, fenol, alginat dan fucoidan yang dapat digunakan sebagai bahan pangan dan obat-obatan ${ }^{(11)}$. Pada penelitian sebelum ekstrak rumput laut coklat (S. polycystum) dibuat sediaan nanopartikel dan di uji

Tabel 6. Rata-rata kadar profil lipid serum tikus (mg/dL) pada hari ke-0, ke-14 dan ke-36.

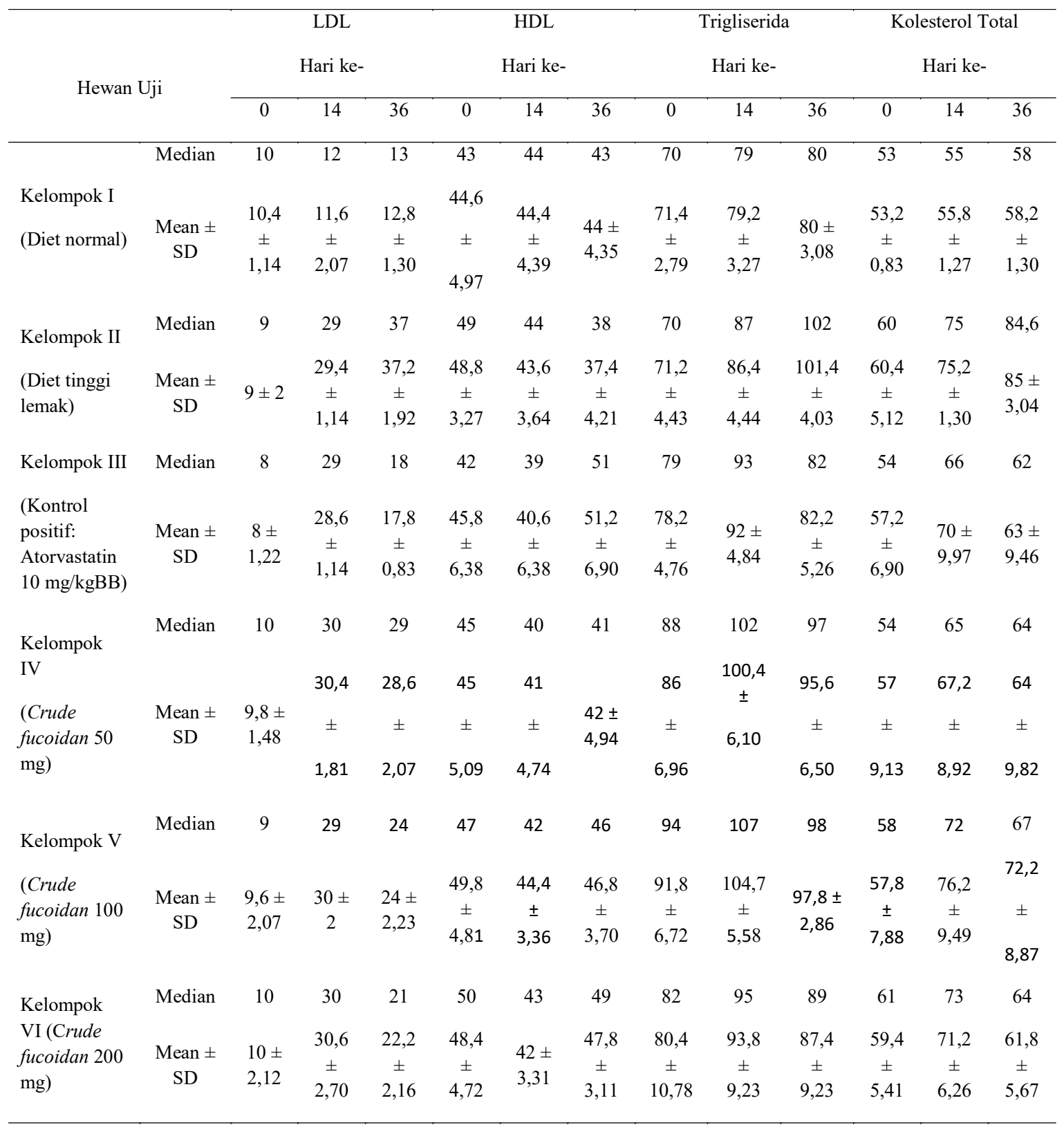


efek anti platelet secara in vivo dan diketahui bahwa sediaan ekstrak rumput laut coklat (S. polycystum) dapat memperpanjang waktu pendarahan dan waktu koagulasi pada tikus dimana senyawa fucoidan yang terdapat pada rumput laut coklat (Sargassum sp.) dapat mencegah agregasi trombosit yang diinduksi oleh trombin. Senyawa flavonoid dapat menghambat berbagai tahap pembentukan aterosklerosis, kerusakan endotel, aktivasi leukosit, adhesi, agregasi, dan sekresi trombosit ${ }^{(25)}$.

\section{SIMPULAN}

Pemberian crude fucoidan dosis $200 \mathrm{mg}$ dapat menurunkan kadar kolesterol total, LDL, Trigliserida dan meningkatkan kadar HDL serum tikus putih jantan yang diberi pakan diet tinggi lemak selama 35 hari dengan indeks aterogenik sebesar 0,34 ,

\section{UCAPAN TERIMA KASIH}

Ucapan terima kasih kami sampaikan kepada Kemenristek DIKTI yang telah membiayai penelitian ini melalui SIMLITABMAS Hibah Tim Pasca sarjana tahun $2017 / 2018$.

\section{DAFTAR PUSTAKA}

1. Widowati W. Peran antioksidan sebagai agen hipokolesterolemia, pencegah oksidasi lipid dan aterosklerosis [Skripsi]. Bandung: Fakultas Kedokteran Universitas Kristen Maranatha; 2007.

2. World Health Organization. Global Atlas on cardiovascular disease prevention and control. Published by the World Health Organization in collaboration with the World Heart Federation and the World Stroke Organization [Internet]. 2011. p 3 [cited 4 Maret 2018]. Available from: https://www.whqlibdoc. who.int/publications/2011/9789241564373_eng.pdf.

3. Badan Penelitian dan Pengembangan Kesehatan. Pokok-pokok hasil Risdeskas Indonesia Tahun 2013. Lembaga Penerbit Blitbangkes [Internet]. 2014. Available from: www.depkes.go.id/resources/ download/general.

4. Wong AP, Mohamed AL, Niedzwiecki A. Atherosclerosis and the cholesterol theory: A Reappraisal. World Journal of Cardiovascular Disease. 2016 Januari:6(11):391-409.

5. Sakakura K, Nakato M, Otsuka F, Ladich E, Kolodgie FD, Virmani R. Pathophysiology of Atherosclerosis Plaque Progression. Journal Review, CVPath Institue, Inc. 2013 Juni;22(6):399-411.

6. Linna M. Oxidized LDL Lipids as a risk factor for atherosklerosis. Faculty of Medicine University of
Turku; 2014:12-24.

7. Perhimpunan Dokter Spesialis Kardiovaskular Indonesia. Pedoman tatalaksana dislipidemia. Edisi 1. Perhimpunan Dokter Spesialis Kardiovaskular Indonesia. Jakarta. 2013:41.

8. Sever PS, Dahloi B, Poulter NR, Wedel H, Beevers G, Caulfield $\mathrm{M}$ et al. Prevention of coronary and stroke events with atorvastatin in hypertensive patients who have average or lower-than-average cholesterol concentrations, in the Anglo-Scandinavian Cardiac Outcomes Trial- Lipid Lowering Arm (ASCOTLLA): a multicentre randomised controlled trial. Dalam Medicinus: Dyslipidemia. Scientific Journal of Pharmaceutical Development and Medical Application. 2013 December;26(1):43-60.

9. Badan Pengawasan Obat dan Makanan Republik Indonesia. Informatorium Obat Nasional Indonesia 2014 (IONI). Jakarta; 2014.

10. Putra SE. Alga laut sebagai biotarget industri [Internet]. 2012. [cited 11 Februari 2018] Available from: http:// www.energi. lipi.go.id/utama.cgi?artikel211586897. htm.

11. Pakidi CS, Sawoyo HS. Potensi dan pemanfaatan bahan aktif alga cokelat Sargassum Sp. Balai Penelitian dan Pengembangan Budidaya Air Payau, Maros. 2016 Juni;5(2):488-98.

12. Sinurat, E. dan Kusumawati, R. Optimasi metode ekstraksi fukoidan kasar dari rumput laut cokelat Sargassum Binderi Sonder. JPB Kelautan dan Perikanan. Jakarta. 2017 November 23;12(2):125-34.

13. Kartinngsih, Fitria, Abdillah S. Preparation of nanoparticles of the extract of the brown seaweed (Sargassum polycystum) and in vivo anti platelet testing. International Journal of ChemTech Research. 2018;11(6):190-95.

14. Ningrum RRDS, Hardoko, Sosmito BB. Pengaruh ekstrak kasar fukoidan alga coklat Sargassum polycystum sebagai antikankerterhadap viabilitas sel HELA. THPI Student Journal. 2013;1(1):83-92

15. Diachanty S, Nurjanah, Abdullah A. Aktivitas antioksidan berbagai jenis rumput laut coklat dari perairan kepulauan seribu. Departemen Teknologi Hasil Perairan, Fakultas Perikanan dan Ilmu Kelautan, Institut Pertanian Bogor; 2017:20(2).

16. Isdadiyanto S. Kadar apoprotein A dan apoprotein B serum darah tikus putih Sprague Dawley hiperlipidemia setelah diberi cangkang udang laut (Penaeus monodon F.). Buletin Anatomi dan Fisiologi; 2015:23(2):101-8.

17. Herpandi, Astawan M, Wresdiyati T, Sri PN. Perbandingan profil lipida, kolesterol digesta dan asam propionat pada tikus dengan diet tepung rumput laut. Jurnal Teknologi dan Industri Pangan. 2006 Mei;7(3):227-32.

18. Smith BVSc, Mangkoewidjojo S. Pemeliharaan, pembiakan dan penggunaan hewan percobaan di daerah tropis. International Development Program of Australian Universities and Collages: Penerbit Universitas Indonesia; 1988. 39 p.

19. Riesanti DG, Padaga C, Herawati. HDL levels, 
LDL levels and aorta's histopathologic appearance hypercholesterolemia rats (Rattus norvegicus) of effect therapy water extract of mango's mistletoe (Dendrophthoe pentandra). Universitas Brawijaya. Malang. 2012.

20. Herwiyarirasanta, BA. Effect of black soybean extract supplementation in low density lipoprotein level of rats (Rattus norvegicus) with high fat diet. Science Article Universitas Airlangga. Surabaya. 2010 Juni;9(3):21721.

21. Herperion, Kurniawaty E, Susantiningsih T. The effect of jengkol's seed ethanol extract (Pithocelobium lobatum Benth.) to triglyceride level in male Sprague Dawley rats (Rattus novegicus) induced by alloxan. Medical Faculty of Lampung University. 2004;9(3):2337-3776.

22. Ismawati, Oenzil F, Yanwirasti, Terizel E. Analisis konsentrasi low density lipoprotein teroksidasi serum pada tahapan aterosklerosis. Jurnal Kedokteran Brawijaya. 2017;29(4):348-52.
23. Yuliantini E, Sari AP, Nur E. Hubungan asupan energi, lemak dan serat dengan rasio kadar kolesterol totalHDL (intake of energy, fat and fiber content with the ratio of total colesterol-HDL). Poltekkes Kemenkes Bengulu, Bengkulu: 2015 Des 10;38(2):139-47.

24. Rini DRS. Hubungan asupan karbohidrat dan lemak dengan kadar profil lipid pada pasien jantung koroner rawat jalan di RSUD Dr. Moewardi Surakarta. Naskah Publikasi Ilmiah. 2015.

25. Kartiningsih, Fitria, Abdillah S. Preparation of nanoparticle of the extract of the brown seaweed (Sargassum polycystum) and in vivo anti platelet testing. International Journal of ChemTech Research 2018;11(6):190-95. 